\title{
Kecerdasan Emosional dan Kecerdasan Spiritual Terhadap Etos Kerja Karyawan
}

\author{
Imam Syawali, Ahmad Suriadi, dan Shanty Komalasari \\ Universitas Islam Negeri Antasari Banjarmasin
}

\begin{abstract}
This study aims to determine the effect of emotional intelligence and spiritual intelligence on the work ethic of employees in the South Kalimantan Provincial Health Office. This type of research is field research with a quantitative approach. The population in this study were employees at the South Kalimantan Provincial Health Office and 62 respondents were the respondents. Based on this research, the results obtained: 1) There is a significant influence between emotional intelligence on the work ethic of employees in the South Kalimantan Provincial Health Office, with a significance level of 0,000 ( $p$ value <0,05) and an effective contribution of 40,4\%.2) There is a significant influence between spiritual intelligence on the work ethic of employees in the South Kalimantan Provincial Health Office, with a significance level of 0,000 ( $p$ value $<0,05)$ and an effective contribution of 59,4\%.3) There is a significant influence simultaneously or together between emotional intelligence and spiritual intelligence on the work ethic of employees in the office environment of the South Kalimantan Provincial Health Office, with a significance value or $p$ value is 0,000 ( $p$ value $<0,05$ ), as well as the influence which were given simultaneously or together amounting to $59,5 \%$.
\end{abstract}

Keywords: emotional intelligence; spiritual intelligence; South Kalimantan Provincial Health Office; work ethic.

\begin{abstract}
Abstrak
Penelitian ini bertujuan untuk mengetahui pengaruh kecerdasan emosional dan kecerdasan spiritual terhadap etos kerja karyawan di lingkungan kantor Dinas Kesehatan Provinsi Kalimantan Selatan. Jenis penelitian ini adalah penelitian lapangan (field research) dengan pendekatan kuantitatif. Populasi dalam penelitian ini adalah karyawan di kantor Dinas Kesehatan Provinsi Kalimantan Selatan dan yang menjadi responden berjumlah 62 orang. Berdasarkan penelitian ini, didapatkan hasil: 1) Terdapat pengaruh yang signifikan antara kecerdasan emosional terhadap etos kerja karyawan di lingkungan kantor Dinas Kesehatan Provinsi Kalimantan Selatan, dengan taraf signifikansi 0,000 ( $\mathrm{p}$ value $<0,05$ ) dan sumbangan efektif sebesar 40,4\%. 2) Terdapat pengaruh yang signifikan antara kecerdasan spiritual terhadap etos kerja karyawan di lingkungan kantor Dinas Kesehatan Provinsi Kalimantan Selatan, dengan taraf signifikansi 0,000 ( $p$ value $<0,05$ ) dan sumbangan efektif sebesar yaitu sebesar 59,4\%. 3) Terdapat pengaruh yang signifikan secara simultan atau bersama-sama antara kecerdasan emosional dan kecerdasan spiritual terhadap etos kerja karyawan di lingkungan kantor Dinas Kesehatan Provinsi Kalimantan Selatan, dengan nilai signifikansi atau p value adalah 0,000 ( $p$ value $<0,05)$, serta pengaruh yang diberikan secara simultan atau bersama-sama sebesar 59,5\%.
\end{abstract}


Kata kunci: kecerdasan emosional; kecerdasan spiritual; Dinas Kesehatan Provinsi Kalimantan Selatan; etos kerja.

Sumber Daya Manusia (SDM) adalah hal yang selalu menjadi perhatian utama terhadap segala aktivitas khususnya dalam suatu organisasi. Manusia yang berada di dalam suatu organisasi memiliki kewenangan untuk menjalankan serta menentukan segala tindakan yang akan dilakukan dalam setiap aktivitas. Hal tersebut menjadikan peranan SDM menjadi sangat dibutuhkan untuk berkontribusi bagi suatu organisasi (Aditya Reza, 2010). Peranan karyawan dalam organisasi berfungsi sebagai perencana, pelaksana serta pengendali segala aktivitas yang berperan besar dalam kemajuan dan keberhasilan organisasi tersebut. Meskipun berbagai hal yang diperlukan telah terpenuhi, namun tanpa peran karyawan sulit bagi organisasi untuk menjalankan setiap kegiatannya. Karena karyawanlah yang menjadi tokoh utama untuk dapat menjadi penggerak dalam segala aktivitas (Septianto, 2010).

Anoraga menyatakan bahwa individu yang ingin mencapai keberhasilan harus mempunyai pemikiran atau perspektif terhadap kerja sebagai suatu hal yang memiliki nilai dalam kehidupannya sebagai manusia. Adanya pengabdian atau pengorbanan tenaga, pikiran, kesungguhan serta usaha yang tulus dalam bekerja dari para karyawan merupakan hal yang sangat diperlukan demi tercapainya keberhasilan kerja. Individu yang mempunyai pandangan mendalam terhadap kerja bisa menjadikan individu tersebut bersungguh-sungguh dan tulus menjalankan setiap pekerjaannya. Cara pandang dan bersikap dalam bekerja disebut dengan istilah etos kerja (Andri Hadiansyah \& Rini Purnamasari Yanwar, 2015).

Kemauan dan keinginan untuk mendapatkan atau memberikan hasil kerja yang maksimal dari para karyawan dapat menjadi faktor terbentuknya etos kerja. Sangat penting bagi para karyawan untuk memiliki etos kerja dalam dirinya karena akan berpengaruh juga terhadap pekerjaan yang dilakukan sehingga segala tugas dan kewajiban yang diberikan mampu diselesaikan dengan baik dan efektif. Dengan suatu pencapaian penuh dari etos kerja maka akan berpengaruh terhadap kinerja seseorang ketika menjalankan tugas dan kewajiban berikutnya (Rukmana, 2010). 
Menurut Nurcholish Madjid, etos kerja di dalam Islam ialah bentuk keyakinan orang muslim bahwasanya kerja berkaitan terhadap tujuan hidup, yakni untuk mendapatkan rida Allah SWT. Maka dari itu, perlu untuk dipahami bahwasanya Islam merupakan agama amal atau kerja, maksudnya ialah untuk mendapatkan rida Allah SWT, maka seorang muslim dapat melakukannya dengan bekerja dan beramal saleh disertai dengan ketulusan serta keikhlasan menyembah kepada Allah SWT (Irham, 2012). Agama Islam memang mendorong umatnya agar selalu berusaha keras saat bekerja, dalam Q.S. at-Taubah/9: 105.

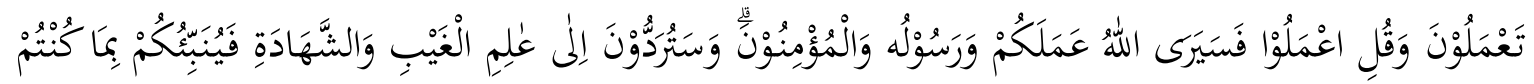

"Dan Katakanlah: 'Bekerjalah kamu, maka Allah akan melihat pekerjaanmu, begitu juga RasulNya dan orang-orang mukmin, dan kamu akan dikembalikan kepada (Allah) Yang Mengetahui akan yang gaib dan yang nyata, lalu diberitakan-Nya kepada kamu apa yang telah kamu kerjakan".

Etos kerja diperlukan dalam dunia kerja baik di organisasi ataupun perusahaan. Etos kerja ini sangat diperlukan juga pada instansi-instansi pemerintahan. Salah satu instansi pemerintahan yang memiliki banyak karyawan sebagai Aparatur Sipil Negara ialah Dinas Kesehatan Provinsi Kalimantan Selatan, karena merupakan suatu instansi atau unsur pelaksana urusan pemerintahan di bidang kesehatan terutama di Provinsi Kalimantan Selatan yang mempunyai program, yakni pembangunan kesehatan. Untuk mewujudkan tujuan tersebut, maka para karyawan yang dalam hal ini disebut Aparatur Sipil Negara (ASN) di kantor Dinas Kesehatan Provinsi Kalimantan Selatan harus memiliki etos kerja yang baik mengingat tugas dan kewajibannya yang besar sebagai bagian dari pelaksana urusan pemerintahan di bidang kesehatan. Hal ini harus diwujudkan dengan perilaku kerja keras, tanggung jawab, ketekunan, semangat, profesionalitas, disiplin, dan lain halnya agar visi dan misi yang ditetapkan dapat dicapai.

Akan tetapi berdasarkan studi pendahuluan berupa wawancara yang dilaksanakan peneliti di kantor Dinas Kesehatan Provinsi Kalimantan Selatan ditemukan tidak semua karyawan di kantor Dinas Kesehatan Provinsi Kalimantan Selatan memiliki etos kerja yang baik, masih ada karyawan yang kurang disiplin untuk mentaati peraturan, menunda-nunda dalam 
menyelesaikan pekerjaan, keterlambatan masuk kerja, keluar kantor saat jam kerja, dan hal-hal lain disebabkan ketidakdisiplinan yang mana hal itu merupakan bagian atau indikator-indikator dari etos kerja seseorang. Beberapa permasalahan tersebut mencerminkan bahwa masih rendahnya etos kerja yang dimiliki oleh para karyawan. Hal tersebut didukung seperti yang ditemukan saat observasi selama peneliti melakukan Praktik Kerja Magang di kantor Dinas Kesehatan Provinsi Kalimantan Selatan.

Hasil penelitian Nugroho mendapati bahwasanya etos kerja dapat dipengaruhi dari beberapa hal yaitu faktor eksternal dan internal. Secara eksternal, hal yang mempengaruhinya yaitu interaksi sosial dan situasi atau kondisi lingkungan kerja. Sedangkan Pachrudianto dalam penelitiannya mendapati bahwa yang bisa memberi pengaruh terhadap etos kerja secara internal ialah kecerdasan emosional atau Emotional Quotient (EQ). Individu yang dengan kecerdasan emosional baik akan bisa menyesuaikan diri terhadap segala situasi yang terjadi di lingkungan manapun berada. Dengan kemampuan ini pula individu akan dapat berperilaku atau membangun hubungan yang baik dengan orang lain serta lingkungan sekitarnya. Individu dengan pengendalian diri akan mampu mengendalikan dirinya dengan baik serta mampu mengatur kawajibannya dalam bekerja seperti kapan pekerjaan itu harus dikerjakan dan diselesaikan, dan lain sebagainya. Hal tersebut membuat individu memiliki pandangan yang positif akan bekerja dan pekerjaan yang dihadapi dapat dilaksanakan dengan sebaik-baiknya (Nugroho, 2014).

Kecerdasan emosional menurut Salovey dan Mayer ialah keahlian untuk memantau perasaan dan emosi pada diri sendiri ataupun orang lain, agar dapat membedakan berbagai informasi yang didapat, sehingga dengan informasi itu dapat dijadikan sebagai pedoman atau tuntunan dalam berpikir dan berperilaku (Rosdaranita, 2017). Menurut Daniel Goleman bahwa kecerdasan emosional adalah kemampuan individu untuk mengenali kondisi perasaan, untuk memotivasi diri sendiri serta mengelola emosi dengan baik pada diri sendiri dan hubungannya dengan orang lain (Choiriah, 2013).

Pada suatu organisasi juga tidak terlepas dari bagaimana para karyawan atau dalam hal ini disebut ASN memberikan makna terhadap pekerjaan yang dilakukannya serta bersikap sesuai norma yang sudah diterapkan ditempat kerja dan kemampuan memberikan makna 
terhadap suatu peristiwa atau keadaan ini disebut dengan istilah kecerdasan spiritual (Ardiansari, 2017).

Kecerdasan spiritual atau Spiritual Quotient (SQ) sebagai kemampuan seseorang dalam menghadapi persoalan makna dan nilai terhadap suatu peristiwa atau tindakan yang dilakukannya. Dengan memberikan makna terhadap suatu hal tersebut, maka dapat membuat individu berperilaku dan menilai arti dari setiap tindakan yang dilakukan. Kecerdasan spiritual menurut Danah Zohar dan Ian Marshall ialah kemampuan ketika menghadapi dan memecahkan persoalan makna dan nilai, yaitu kecerdasan untuk menempatkan perilaku dan hidup kita dalam konteks makna yang lebih luas dan kaya, kecerdasan untuk menilai bahwa tindakan dan jalan hidup seseorang lebih bermakna dibandingkan dengan yang lain. Spiritual Quotient (SQ) merupakan kecerdasan tertinggi (Zohar \& Marshall, 2007). Sedangkan Ginanjar menyatakan SQ merupakan cara seseorang untuk dapat memberikan makna secara spiritual bagi pemikirannya, perilakunya atau suatu peristiwa, serta mampu memberikan rasa moral dan membuat seseorang bisa menyesuaikan diri terhadap norma-norma baru (Ardiansari, 2017).

Berdasarkan latar belakang tersebut, maka peneliti ingin mengetahui apakah ada pengaruh kecerdasan emosional dan kecerdasan spiritual terhadap etos kerja karyawan di lingkungan kantor Dinas Kesehatan Provinsi Kalimantan Selatan.

\section{Metode}

Jenis penelitian ini adalah penelitian lapangan (field research) dengan pendekatan kuantitatif. Jenis kuantitatifnya adalah kuantitatif korelasional dengan tujuan untuk menguji keeratan hubungan diantara variabel-variabel yang diteliti tanpa melakukan manipulasi apapun terhadap variabilitas yang ada pada variabel-variabel yang bersangkutan. Subjek penelitian ini adalah karyawan di lingkungan kantor Dinas Kesehatan Provinsi Kalimantan Selatan sebagai responden. Teknik pengambilan sampel pada penelitian ini adalah teknik purposive sampling. Purposive sampling yaitu suatu cara yang dipakai untuk memilih orang-orang berdasarkan ciri dan sifat yang sudah ditentukan pada sampel (Arikunto, 2010). Adapun kriteria dari penarikan sampel tersebut, yaitu laki-laki dan perempuan usia 20-60 tahun, karyawan berstatus PNS dan non-PNS di kantor Dinas Kesehatan Provinsi Kalimantan Selatan sebagai staff, bekerja dalam 
kurun waktu minimal 1 tahun, tidak termasuk Kepala Dinas, Kepala Bidang, dan Kepala Seksi di kantor Dinas Kesehatan Provinsi Kalimantan Selatan. Sampel pada penelitian ini sebanyak 62 responden berlandaskan pada pernyataan Roscoe yang mengusulkan beberapa pedoman umum dalam pengambilan sampel, salah satunya yaitu besaran sampel penelitian yang pantas atau dapat digunakan untuk melakukan pengamatan ialah antara 30 hingga 500 (Azwar, 2017). Objek penelitian ini yaitu kecerdasan emosional dan kecerdasan spiritual sebagai variabel bebas serta etos kerja sebagai variabel terikat.

Pengumpulan data dalam penelitian ini menggunakan 3 skala psikologi yaitu skala kecerdasan emosional, skala kecerdasan spiritual, dan skala etos kerja yang sudah melalui tahap Professional Judgement, uji validitas, dan uji reliabilitas. Skala kecerdasan emosional disusun berdasarkan pada teori Daniel Goleman tentang aspek-aspek kecerdasan emosional, yaitu kesadaran diri, pengaturan diri, motivasi, empati, dan keterampilan sosial (Goleman, 2016). Skala kecerdasan spiritual disusun berdasarkan pada teori Danah Zohar dan Ian Marshall tentang ciriciri kecerdasan spiritual, yaitu bersikap fleksibel, kesadaran diri yang tinggi, kemampuan untuk menghadapi dan memanfaatkan penderitaan, kemampuan untuk menghadapi dan melampaui rasa sakit, kualitas hidup yang diilhami oleh visi dan nilai-nilai, keengganan untuk menyebabkan kerugian yang tidak perlu, kecenderungan untuk melihat keterkaitan dalam berbagai hal (pandangan holistik), memiliki kecenderungan bertanya, dan bidang mandiri (Zohar \& Marshall, 2007). Dan skala etos kerja disusun berdasarkan pada aspek-aspek yang dikemukakan oleh Sinamo, yakni kerja adalah rahmat, kerja adalah amanah, kerja adalah panggilan, kerja adalah aktualisasi, kerja adalah ibadah, kerja adalah seni, kerja adalah kehormatan, dan kerja adalah pelayanan (Sinamo, 2015).

Untuk uji validitas dilakukan dengan memakai rumus korelasi product moment yang telah terprogramkan dengan bantuan Software SPSS 20 terhadap 30 responden. Dalam hal ini N=30 (jumlah responden) berdasarkan $\mathrm{r}$ tabel sig. 5\%, maka untuk nilai validitas adalah 0,361. Selanjutnya uji reliabilitas dilihat dari nilai Cronbach's Alpha. Jika nilai Alpha > 0,60, maka item dinyatakan reliabel. Hasil dari uji reliabilitas kecerdasan emosional adalah 0,955, reliabilitas kecerdasan spiritual adalah 0,949 , dan reliabilitas etos kerja adalah 0,953. 
Analisis data pada penelitian ini menggunakan teknik analisis regresi linear berganda. Analisis regresi linear berganda ialah suatu teknik analisis yang digunakan pada penelitian yang memiliki dua variabel bebas atau lebih terhadap satu variabel terikat (Sujarweni, 2015). Sebelum melakukan uji analisis, maka dilakukan uji asumsi dasar yaitu uji normalitas dan uji linearitas, serta uji asumsi klasik yaitu uji multikolinieritas dan uji heteroskedastisitas. Proses analisis dibantu dengan menggunakan program komputer IBM SPSS Statistics 20 for Windows.

\section{H a s i 1}

Berikut ini adalah pemaparan mengenai hasil dari uji-uji yang telah dilaksanakan, yakni uji asumsi dasar terdiri dari uji normalitas dan uji linearitas, uji asumsi klasik terdiri dari uji multikolinearitas dan uji heteroskedastisitas, serta uji hipotesis. Untuk lebih jelasnya dapat dilihat sebagai berikut:

Uji Asumsi Dasar

Tabel 1

Uji Normalitas

\begin{tabular}{lrr}
\hline & One-Sample Kolmogorov-Smirnov Test & \\
\hline & & Unstandardized Residual \\
\hline$N$ & & 62 \\
Normal Parameters, & Mean & $0 \mathrm{E}-7$ \\
& Std. Deviation & 4.92364898 \\
Most Extreme Differences & Absolute & .129 \\
& Positive & .129 \\
& Negative & -.071 \\
Kolmogorov-Smirnov Z & & 1.018 \\
Asymp. Sig. (2-tailed) & & .251 \\
\hline
\end{tabular}

Dari tabel 1, diketahui hasil uji normalitas pada variabel kecerdasan emosional, kecerdasan spiritual, dan etos kerja menunjukkan nilai signifikansi kolmogorov-smirnov sebesar $0,251>0,05$. Dikarenakan nilai sig $>0,05$, maka dapat ditarik kesimpulan bahwa sebaran data terdistribusi normal.

Tabel 2

\begin{tabular}{llllll}
\hline & $\begin{array}{l}\text { Sum of } \\
\text { Squares }\end{array}$ & Df & $\begin{array}{l}\text { Mean } \\
\text { Square }\end{array}$ & $F$ & Sig. \\
\hline (Combined) & 2544.504 & 25 & 101.780 & 3.303 & .001 \\
\hline
\end{tabular}




\begin{tabular}{|c|c|c|c|c|c|c|c|}
\hline \multirow{5}{*}{$\begin{array}{l}\text { Etos Kerja* } \\
\text { Kecerdasan } \\
\text { Emosional }\end{array}$} & Between & Linearity & 1474.495 & 1 & 1474.495 & 47.848 & .000 \\
\hline & Groups & Deviation & 1070.008 & 24 & 44.584 & 1.447 & .155 \\
\hline & & from Linearity & & & & & \\
\hline & Within G & & 1109.383 & 36 & 30.816 & & \\
\hline & Total & & 3653.887 & 61 & & & \\
\hline
\end{tabular}

Dari tabel 2, diketahui hasil uji linearitas pada variabel kecerdasan emosional terhadap etos kerja menunjukkan nilai signifikansi 0,000<0,05 $(\mathrm{p}<0,05)$. Artinya terdapat hubungan yang linier secara signifikan antara variabel bebas kecerdasan emosional (X1) dan variabel etos kerja $(\mathrm{Y})$.

Tabel 3

Uji Linearitas Kecerdasan Spiritual Terhadap Etos Kerja

\begin{tabular}{|c|c|c|c|c|c|c|c|}
\hline & & & $\begin{array}{l}\text { Sum of } \\
\text { Squares }\end{array}$ & $D f$ & $\begin{array}{l}\text { Mean } \\
\text { Square }\end{array}$ & $F$ & Sig. \\
\hline $\begin{array}{l}\text { Etos Kerja } \\
*\end{array}$ & $\begin{array}{l}\text { Between } \\
\text { Groups }\end{array}$ & (Combined) & 2556.937 & 26 & 98.344 & 3.138 & .001 \\
\hline \multirow{4}{*}{$\begin{array}{l}\text { Kecerdasan } \\
\text { Spiritual }\end{array}$} & & Linearity & 2172.195 & 1 & 2172.195 & 69.307 & .000 \\
\hline & & $\begin{array}{l}\text { Deviation } \\
\text { from } \\
\text { Linearity }\end{array}$ & 384.742 & 25 & 15.390 & .491 & .966 \\
\hline & \multicolumn{2}{|c|}{ Within Groups } & 1096.950 & 35 & 31.341 & & \\
\hline & \multicolumn{2}{|l|}{ Total } & 3653.887 & 61 & & & \\
\hline
\end{tabular}

Dari tabel 3, diketahui hasil uji linearitas pada variabel kecerdasan spiritual terhadap etos kerja menunjukkan nilai signifikansi 0,000<0,05 $(\mathrm{p}<0,05)$. Artinya terdapat hubungan yang linier secara signifikan antara variabel bebas kecerdasan spiritual (X2) dan variabel etos kerja (Y).

Uji Asumsi Klasik

\section{Tabel 4}

Uji Multikolinieritas

\begin{tabular}{|c|c|c|c|c|c|c|c|}
\hline \multirow[t]{2}{*}{ Model } & \multicolumn{2}{|c|}{$\begin{array}{c}\text { Unstandardized } \\
\text { Coefficients }\end{array}$} & \multirow{2}{*}{$\begin{array}{c}\text { Standardized } \\
\text { Coefficients } \\
\text { Beta }\end{array}$} & \multirow[t]{2}{*}{$T$} & \multirow[t]{2}{*}{ Sig. } & \multicolumn{2}{|c|}{$\begin{array}{c}\text { Collinearity } \\
\text { Statistics }\end{array}$} \\
\hline & B & $\begin{array}{l}\text { Std. } \\
\text { Error }\end{array}$ & & & & Tolerance & VIF \\
\hline 1 (Constant) & 16.169 & 7.486 & & 2.160 & .035 & & \\
\hline
\end{tabular}




\begin{tabular}{llllllll}
\hline Kecerdasan & .051 & .151 & .047 & .341 & .734 & .357 & 2.803 \\
$\begin{array}{l}\text { Emosional } \\
\text { Kecerdasan }\end{array}$ & .721 & .136 & .733 & 5.287 & .000 & .357 & 2.803 \\
\begin{tabular}{l} 
Spiritual \\
\hline
\end{tabular}
\end{tabular}

Dari tabel 4, diketahui hasil uji multikolinieritas pada kedua variabel bebas yaitu untuk hasil pada variabel kecerdasan emosional sebesar VIF=2,803 dan hasil pada variabel kecerdasan spiritual sebesar VIF=2,803. VIF dari hasil uji multikolinieritas masih diantara 1-10. Jadi dapat ditarik kesimpulan bahwa tidak terjadi multikolinieritas atau kemiripan diantara variabel bebas, sehingga memenuhi syarat untuk dianalisis regresi.

Tabel 5

Uji Heteroskedastisitas

\begin{tabular}{|c|c|c|c|c|c|}
\hline & & & $\begin{array}{l}\text { Kecerdasan } \\
\text { Emosional }\end{array}$ & $\begin{array}{c}\text { Kecerdasan } \\
\text { Spiritual }\end{array}$ & $\begin{array}{c}\text { Unstandardized } \\
\text { Residual }\end{array}$ \\
\hline Spearman's & Kecerdasan & Correlation & 1.000 & $.723^{* *}$ & -.067 \\
\hline \multirow[t]{11}{*}{ rho } & Emosional & Coefficient & & & \\
\hline & & Sig. (2-tailed) & . & .000 & .607 \\
\hline & & $N$ & 62 & 62 & 62 \\
\hline & Kecerdasan & Correlation & $.723^{* * *}$ & 1.000 & -.093 \\
\hline & Spiritual & Coefficient & & & \\
\hline & & Sig. (2-tailed) & .000 & & .473 \\
\hline & & $N$ & 62 & 62 & 62 \\
\hline & Unstandardized & Correlation & -.067 & -.093 & 1.000 \\
\hline & Residual & Coefficient & & & \\
\hline & & Sig. (2-tailed) & 607 & .473 & \\
\hline & & $N$ & 62 & 62 & 62 \\
\hline
\end{tabular}

Dari tabel 5, diketahui hasil uji heteroskedastisitas didapatkan hasil bahwa untuk variabel bebas yakni kecerdasan emosional menghasilkan nilai 0,607 $>0,05$ (sig $>0,05)$. Sedangkan pada kecerdasan spiritual menghasilkan nilai 0,473 >0,05 (sig > 0,05). Maka dapat ditarik kesimpulan bahwa pada model regresi tidak mengandung gejala heteroskedastisitas, berarti untuk pengujian model regresi dapat dilanjutkan.

\section{Uji Hipotesis}

Hipotesis yang ada pada penelitian ini memiliki dua hipotesis minor dan satu hipotesis mayor yang akan diuji. Uji hipotesis minor yakni hipotesis yang terdiri atas beberapa bagian dari 
hipotesis mayor (satu variabel bebas dengan variabel terikat). Hipotesis minor yang akan diuji, yaitu:

Uji hipotesis minor X1, yakni Ha: Terdapat pengaruh yang signifikan antara kecerdasan emosional terhadap etos kerja karyawan di lingkungan kantor Dinas Kesehatan Provinsi Kalimantan Selatan. Sedangkan Ho: Tidak terdapat pengaruh yang signifikan antara kecerdasan emosional terhadap etos kerja karyawan di lingkungan kantor Dinas Kesehatan Provinsi Kalimantan Selatan.

Pada penelitian ini dilakukan analisis regresi sederhana untuk mengetahui pengaruh secara parsial atau sendiri-sendiri bagian-bagian dari analisis berganda. Hasil analisis regresi sederhana untuk pengaruh variabel kecerdasan emosional terhadap etos kerja menunjukkan nilai signifikansi sebesar 0,000<0,05 ( $\mathrm{p}$ value $<0,05$ ), artinya terdapat pengaruh yang signifikan antara kecerdasan emosional terhadap etos kerja karyawan di lingkungan kantor Dinas Kesehatan Provinsi Kalimantan Selatan. Untuk mengetahui besaran pengaruh yang diberikan, berikut ini adalah tabel Model Summary hasil analisis regresi sederhana kecerdasan emosional terhadap etos kerja:

Tabel 6

\begin{tabular}{llrrrr} 
Model & $R$ & R Square & Adjusted $R$ Square & \multicolumn{2}{c}{$\begin{array}{c}\text { Std. Error of the } \\
\text { Estimate }\end{array}$} \\
\hline 1 & $.635^{\mathrm{a}}$ & .404 & .394 & 6.027 \\
\hline
\end{tabular}

Dari tabel 6, diketahui bahwa untuk nilai koefisien determinan ( $R$ Square) sebesar 0,404. Hal tersebut menunjukkan bahwa variabel bebas kecerdasan emosional memberi sumbangan efektif terhadap variabel terikat etos kerja sebesar $40,4 \%$.

Selanjutnya uji hipotesis minor X2, yakni Ha: Terdapat pengaruh yang signifikan antara kecerdasan spiritual terhadap etos kerja karyawan di lingkungan kantor Dinas Kesehatan Provinsi Kalimantan Selatan. Sedangkan Ho: Tidak terdapat pengaruh yang signifikan antara kecerdasan spiritual terhadap etos kerja karyawan di lingkungan kantor Dinas Kesehatan Provinsi Kalimantan Selatan. 
Hasil analisis regresi sederhana untuk pengaruh variabel kecerdasan spiritual terhadap etos kerja menunjukkan nilai signifikansi sebesar 0,000 <0,05 ( $\mathrm{p}$ value $<0,05$ ), artinya terdapat pengaruh yang signifikan antara kecerdasan spiritual terhadap etos kerja karyawan di lingkungan kantor Dinas Kesehatan Provinsi Kalimantan Selatan. Untuk mengetahui besaran pengaruh yang diberikan, berikut ini adalah tabel Model Summary hasil analisis regresi sederhana kecerdasan spiritual terhadap etos kerja:

Tabel 7

Model Summary

\begin{tabular}{lrrrr}
\hline Model & $R$ & R Square & Adjusted R Square & $\begin{array}{c}\text { Std. Error of the } \\
\text { Estimate }\end{array}$ \\
\hline 1 & $.771^{\mathrm{a}}$ & .594 & .588 & 4.969 \\
\hline
\end{tabular}

Dari tabel 7, diketahui bahwa untuk nilai koefisien determinan ( $R$ Square) sebesar 0,594. Hal tersebut menunjukkan bahwa variabel bebas kecerdasan spiritual memberi sumbangan efektif terhadap variabel terikat etos kerja sebesar 59,4\%.

Uji Hipotesis Mayor yakni hipotesis yang mencakup kaitan seluruh variabel dan objek penelitian. Hipotesis mayor yang akan diuji, yaitu:

Ha: Terdapat pengaruh yang signifikan antara kecerdasan emosional dan kecerdasan spiritual terhadap etos kerja karyawan di lingkungan kantor Dinas Kesehatan Provinsi Kalimantan Selatan. Sedangkan untuk Ho: Tidak terdapat pengaruh yang signifikan antara kecerdasan emosional dan kecerdasan spiritual terhadap etos kerja karyawan di lingkungan kantor Dinas Kesehatan Provinsi Kalimantan Selatan.

Hasil analisis regresi berganda menunjukkan nilai signifikansi 0,000 $<0,05$ (taraf signifikansi atau $\mathrm{p}$ value $<0,05)$. Sehingga ditarik kesimpulan bahwa terdapat pengaruh kecerdasan emosional dan kecerdasan spiritual terhadap etos kerja karyawan di lingkungan kantor Dinas Kesehatan Provinsi Kalimantan Selatan. Untuk mengetahui besaran pengaruh yang diberikan, berikut ini adalah tabel Model Summary hasil analisis regresi berganda: 


\section{Tabel 8}

Model Summary

\begin{tabular}{lrrrr}
\hline Model & $R$ & R Square & Adjusted R Square & \multicolumn{2}{c}{$\begin{array}{c}\text { Std. Error of the } \\
\text { Estimate }\end{array}$} \\
\hline 1 & $.772^{\text {a }}$ & .595 & .582 & 5.006 \\
\hline
\end{tabular}

Dari tabel 8, diketahui bahwa untuk nilai koefisien determinan ( $R$ Square) sebesar 0,595. Artinya untuk variabel bebas kecerdasan emosional dan kecerdasan spiritual secara bersamasama atau simultan memberi sumbangan efektif atau pengaruhnya terhadap variabel terikat etos kerja sebesar $59,5 \%$.

\section{Pembahasan}

Mochtar Buchori mendefinisikan etos kerja adalah suatu bentuk penilaian atau cara pandang individu atau kelompok terhadap kerja dalam bersikap serta berperilaku ketika melakukan pekerjaannya (Sari Lubis, 2018). Sinamo menyatakan, etos kerja ialah seperangkat perilaku positif yang berakar pada keyakinan fundamental yang disertai komitmen total pada paradigma kerja yang integral (Sinamo, 2015). Jadi, etos kerja ialah sikap atau perspektif seseorang terhadap kerja yang mempengaruhi tindakannya dalam menjalankan pekerjaan disertai kesadaran dan keinginan sendiri untuk patuh terhadap aturan dan nilai yang telah ditetapkan serta melakukan pekerjaan sebaik mungkin agar memperoleh hasil kerja yang optimal demi tercapainya tujuan organisasi. Gambaran etos kerja ditinjau melalui aspek-aspek yang dikemukakan oleh Jansen Sinamo yang dimasukkan pada skala disesuaikan berdasarkan teori yang telah dijelaskan oleh peneliti pada definisi operasional dan landasan teori. Aspek-aspek etos kerja tersebut diantaranya, yakni kerja adalah rahmat, kerja adalah amanah, kerja adalah panggilan, kerja adalah aktualisasi, kerja adalah ibadah, kerja adalah seni, kerja adalah kehormatan, dan kerja adalah pelayanan.

Faktor yang berpengaruh terhadap etos kerja diantaranya adalah kecerdasan emosional dan kecerdasan spiritual. Daniel Goleman menyatakan kecerdasan emosional atau Emotional Quotient (EQ) ialah kemampuan individu untuk mengenali kondisi perasaannya, untuk memotivasi diri sendiri serta mengelola emosi dengan baik pada diri sendiri, dan hubungannya dengan orang lain (Goleman, 2016). Sedangkan, kecerdasan spiritual atau Spiritual Quotient (SQ) 
menurut Zohar dan Marshall ialah kecerdasan untuk menghadapi dan memecahkan persoalan makna dan nilai, yaitu kecerdasan untuk menempatkan perilaku dan hidup kita dalam konteks makna yang lebih luas dan kaya, kemampuan untuk memberi nilai bahwa tindakan, dan jalan hidup individu itu lebih bermakna dibanding dengan hal lain (Rosdaranita, 2017).

Gambaran EQ dilihat dari beberapa aspek yang telah disampaikan Daniel Goleman, dimana beberapa aspek itu berhubungan dengan perilaku yang menggambarkan EQ individu. Beberapa aspek itu, yakni kesadaran diri, pengaturan diri, motivasi, empati, dan keterampilan sosial (Goleman, 2016). Sedangkan gambaran SQ merujuk dari indikator yang dipaparkan Zohar dan Marshall, dimana indikator itu berhubungan tentang perilaku yang menggambarkan kecerdasan spiritual individu. Indikator tersebut diantaranya bersikap fleksibel, kesadaran diri yang tinggi, mampu untuk menghadapi dan memanfaatkan penderitaan, kemampuan untuk menghadapi dan melampaui rasa sakit, kualitas hidup yang diilhami oleh visi dan nilai, keengganan untuk menyebabkan kerugian yang tidak perlu, berpandangan holistik, memiliki kecenderungan bertanya, serta bidang mandiri (Zohar \& Marshall, 2007).

Pada penelitian ini, peneliti mengajukan tiga hipotesis kerja (Ha) dan ketiga hipotesis tersebut dapat diterima. Berdasarkan hasil uji hipotesis pertama dan untuk menjawab rumusan masalah tersebut, diketahui dengan jelas bahwa terdapat pengaruh yang signifikan antara kecerdasan emosional terhadap etos kerja karyawan di lingkungan kantor Dinas Kesehatan Provinsi Kalimantan Selatan, dengan memberi sumbangan efektif sebesar 40,4\%.

Kecerdasan emosional mampu meningkatkan etos kerja seseorang dalam bekerja. Orang yang memiliki kecerdasan emosional baik personal atau sosial di lingkungan kerjanya dapat mengelola perasaan atau kecemasan agar kemampuannya dalam bekerja tidak terganggu. Orang yang mempunyai kemampuan ini juga bisa menciptakan suatu hubungan yang baik kepada orang lain di tempat kerja sehingga dapat mengurangi perasaan tegang dalam diri setiap orang. Kecerdasan emosi tentunya juga dapat menjadikan ketahanan serta semangat dalam bekerja seseorang meningkat, akibatnya dapat memunculkan motivasi yang tinggi untuk berprestasi dalam bekerja. Kemampuan untuk mengelola serta mengatur emosi dengan baik tentunya akan berpengaruh terhadap cara pandang serta perilaku seseorang dalam bekerja yang disebut etos kerja. Semakin tingginya kecerdasan emosi yang dimiliki para karyawan, maka akan semakin 
tinggi juga tingkat etos kerja yang dimilikinya. Sebaliknya jika kecerdasan emosionalnya rendah, maka etos kerja yang dimilikinya juga akan rendah atau kurang (Nugroho, 2014).

Kemudian berdasarkan hasil uji hipotesis kedua dan untuk menjawab rumusan masalah tersebut, diketahui dengan jelas bahwa terdapat pengaruh yang signifikan antara kecerdasan spiritual terhadap etos kerja karyawan di lingkungan kantor Dinas Kesehatan Provinsi Kalimantan Selatan, dengan memberi sumbangan efektif sebesar 59,4\%.

Kecerdasan spiritual dapat membuat individu untuk berpikir dengan kreatif, memiliki wawasan yang luas sehingga menjadikan individu tersebut dalam bekerja menjadi lebih baik. Kecerdasan spiritual erat kaitannya dengan kemampuan individu dalam memberikan makna dalam setiap hal ataupun peristiwa secara positif serta mampu dalam menyelesaikan suatu permasalahan apapun kondisinya. Seseorang yang semakin cerdas spiritualnya, ketika menjalankan suatu pekerjaan dan itu merupakan bagian dari tanggung jawabnya akan merasakan kepuasan dalam bekerja. Hal tersebut karena cerdas secara spiritual artinya seseorang telah mempunyai kesadaran yang tinggi serta pengabdian dan tanggung jawab yang penuh dalam bekerja (Ardiansari, 2017).

Selanjutnya, berdasarkan hasil uji hipotesis ketiga dan untuk menjawab rumusan masalah tersebut, diketahui dengan jelas bahwa terdapat pengaruh yang signifikan antara kecerdasan emosional dan kecerdasan spiritual terhadap etos kerja karyawan di lingkungan kantor Dinas Kesehatan Provinsi Kalimantan Selatan, dengan memberi sumbangan efektif atau pengaruhnya sebesar $59,5 \%$, sedangkan $40,5 \%$ dipengaruhi oleh faktor lain yang tidak termasuk dalam penelitian ini.

Sesuai dengan hasil analisis, maka ditemukan atau dapat ditarik kesimpulan bahwa terdapat pengaruh yang signifikan antara kecerdasan emosional dan kecerdasan spiritual terhadap etos kerja karyawan di lingkungan kantor Dinas Kesehatan Provinsi Kalimantan Selatan. Hal ini menyatakan bahwa etos kerja seseorang tidak mutlak karena pengaruh dari kecerdasan emosional dan kecerdasan spiritual, antara kecerdasan emosional dan kecerdasan spiritual memang dapat memberikan pengaruh terhadap etos kerja, akan tetapi seseorang yang beretos kerja tinggi dapat dipengaruhi juga dikarenakan beberapa faktor luar yang tidak diteliti pada penelitian ini. Hal itu dibuktikan dari hasil penelitian yang sudah dilaksanakan oleh Diyah 
Fitriyani, Ocky Sundari dan Johnson Dongoran dengan judul "Faktor-faktor Yang Mempengaruhi Etos Kerja Pegawai Kecamatan Sidorejo Salatiga". Pada penelitian ini disebutkan beberapa faktor yang dapat memberi pengaruh pada etos kerja diantaranya gaji, agama, disiplin, kondisi lingkungan, tingkat pendidikan, struktur ekonomi, dan motivasi (Fitriyani dkk., 2019). Begitu juga penelitian dari Karyoto yang berjudul “Faktor-faktor Yang Mempengaruhi Etos Kerja Karyawan pada Rumah Sakit Qolbu Insan Mandiri Kabupaten Batang". Pada penelitian ini disebutkan faktor yang dapat mempengaruhi etos kerja yakni hubungan antarmanusia (Human Relation) dan kondisi fisik lingkungan (Karyoto, 2017).

Pentingnya etos kerja dalam dunia pekerjaan terutama pada karyawan disuatu organisasi, perusahaan ataupun instansi-instansi pemerintahan. Ketika seorang karyawan mampu menilai hasil kerja dengan sangat positif, maka akan dapat meningkatkan etos kerja pada dirinya. Semakin tinggi etos kerja yang dimiliki karyawan, membuat kinerjanya meningkat di tempat kerja. Begitu juga sebaliknya, semakin rendahnya etos kerja yang dimiliki karyawan, maka kinerjanya mengalami penurunan dalam melakukan pekerjaan. Individu yang mempunyai etos kerja tinggi dapat dilihat dari perilakunya, yakni bersikap adil, berusaha dengan keras, bertanggung jawab, displin atau tidak menunda-nunda dalam menyelesaikan pekerjaan, mau bekerja sama, saling menghormati, menghargai dengan sesama rekan kerja, sehingga mampu memberikan kontribusi positif bagi kemajuan organisasi ataupun instansi terkait.

Kekurangan atau keterbatasan yang terdapat dalam penelitian ini ada beberapa hal, yaitu dalam penelitian ini untuk faktor yang berpengaruh terhadap etos kerja hanya terdiri atas dua variabel, yakni kecerdasan emosional dan kecerdasan spiritual, sedangkan masih terdapat banyaknya faktor lainnya yang dapat memberikan pengaruhnya terkait etos kerja. Dalam hal wawancara yang dilakukan, penelitian ini hanya sebatas melakukan wawancara untuk studi pendahuluan. Adanya keterbatasan peneliti ketika melakukan pengambilan data di lapangan yaitu lamanya waktu yang dibutuhkan dalam pengambilan data.

\section{Kesimpulan}

Dari hasil analisis data dalam penelitian mengenai pengaruh kecerdasan emosional dan kecerdasan spiritual terhadap etos kerja karyawan di lingkungan kantor Dinas Kesehatan 
Provinsi Kalimantan Selatan, maka dapat disimpulkan bahwa terdapat pengaruh yang signifikan antara kecerdasan emosional terhadap etos kerja pada penelitian ini sebesar 40,4\%. Serta terdapat pengaruh yang signifikan antara kecerdasan spiritual terhadap etos kerja, dengan persentase sebesar 59,4\%. Selanjutnya, terdapat pengaruh yang signifikan antara kecerdasan emosional dan kecerdasan spiritual terhadap etos kerja, dengan pengaruh yang diberikan sebesar 59,5\%. Yang artinya kecerdasan emosional dan kecerdasan spiritual dapat mempengaruhi etos kerja karyawan di lingkungan kantor Dinas Kesehatan Provinsi Kalimantan Selatan baik secara bersama-sama (simultan) ataupun secara sendiri-sendiri (parsial).

\section{Saran}

Penelitian ini menunjukkan adanya pengaruh kecerdasan emosional dan kecerdasan spiritual terhadap etos kerja karyawan di lingkungan kantor Dinas Kesehatan Provinsi Kalimantan Selatan. Peneliti menyarankan bagi kantor Dinas Kesehatan Provinsi Kalimantan Selatan hendaknya berupaya meningkatkan etos kerja karyawannya, tidak hanya melalui pelatihan atau pengembangan kecerdasan emosional dan kecerdasan spiritual, namun juga memperhatikan faktor-faktor lain yang dapat meningkatkan etos kerja. Karena etos kerja akan dapat memberikan dampak positif bagi instansi atau organisasi itu sendiri. Bagi peneliti selanjutnya, diharapkan untuk bisa memakai teori lain yang berbeda dengan tujuan untuk memperkaya dan memperluas pembahasan penelitian terkait variabel kecerdasan emosional, kecerdasan spiritual, dan etos kerja. Berdasar pada hasil penelitian menunjukkan masih terdapat banyak variabel yang dapat mempengaruhi etos kerja serta dapat pula bagi peneliti selanjutnya untuk meneliti memakai metode lain seperti metode kualitatif untuk memperoleh hasil yang lebih mendalam terkait faktor yang dapat mempengaruhi etos kerja.

\section{Referensi}

Aditya Reza, R. (2010). Pengaruh Gaya Kepemimpinan, Motivasi dan Disiplin Kerja Terhadap Kinerja Karyawan PT Sinar Sentosa Perkasa Banjarnegara. Fakultas Ekonomi Universitas Diponegoro.

Andri Hadiansyah, \& Rini Purnamasari Yanwar. (n.d.). Pengaruh Etos Kerja Terhadap Kinerja Karyawan PT. AE.

Ardiansari, D. A. (2017). Hubungan Kecerdasan Spiritual Dengan Organizational Citizenship Behavior Pada Karyawan. Fakultas Psikologi Universitas Muhammadiyah Malang. 
Arikunto, S. (2010). Prosedur Penelitian: Suatu Pendekatan Praktik. Rineka Cipta.

Azwar, S. (2017). Metode Penelitian Psikologi II. Pustaka Pelajar.

Choiriah, A. (2013). Pengaruh Kecerdasan Emosional, Kecerdasan Intelektual, Kecerdasan Spiritual, dan Etika Profesi Terhadap Kinerja Auditor Dalam Kantor Akuntan Publik (Studi Empiris Pada Auditor dalam Kantor Akuntan Publik di Kota Padang dan Pekanbaru). Fakultas Ekonomi Universitas Negeri Padang.

Fitriyani, D., Sundari, O., \& Dongoran, J. (2019). Faktor-faktor Yang Mempengaruhi Etos Kerja Pegawai Kecamatan Sidorejo Salatiga. Jurnal Ilmu Sosial dan Humaniora, Vol. 8, No. 1.

Goleman, D. (2016). Kecerdasan Emosi Untuk Mencapai Puncak Prestasi. PT Gramedia Pustaka Utama.

Irham, M. (2012). Etos Kerja Dalam Perspektif Islam. Jurnal Substantia, Vol. 14 No. 1, 11-24.

Karyoto. (2017). Faktor-Faktor Yang Mempengaruhi Etos Kerja Karyawan pada Rumah Sakit Qolbu Insan Mandiri Kabupaten Batang. IC-Tech, Volume XII No. 2.

Nugroho, A. S. (2014). Hubungan Antara Kecerdasan Emosional dan Etos Kerja Pada Pegawai Negeri Sipil Kota Yogyakarta. Fakultas Psikologi Universitas Sanata Dharma.

Rosdaranita, A. D. (2017). Pengaruh Kecerdasan Spiritual dan Kecerdasan Emosional Terhadap Kinerja Karyawan di CV. Sidiq Manajemen Yogyakarta. Fakultas Dakwah dan Komunikasi Universitas Islam Negeri Sunan Kalijaga.

Rukmana, W. E. (2010). Analisis Pengaruh Human Relation (Hubungan Antar Manusia) dan Kondisi Fisik Lingkungan Tehadap Etos Kerja dan Kinerja Karyawan Dedy Jaya Plaza Tegal. Fakultas Ekonomi Universitas Diponegoro.

Sari Lubis, A. (2018). Pengaruh Kompetensi, Budaya Organisasi, dan Etos Kerja Terhadap Kinerja Pegawai Kantor Camat Batang Kuis Kabupaten Deli Serdang. Fakultas Ekonomi dan Bisnis Islam Universitas Islam Negeri Sumatera Utara.

Septianto, D. (2010). Pengaruh Lingkungan Kerja dan Stres Kerja Terhadap Kinerja Karyawan. Fakultas Ekonomi Universitas Diponegoro.

Sinamo, J. (2015). 8 Etos Kerja Profesional. Institut Darma Mahardika.

Sujarweni, V. W. (2015). SPSS Untuk Penelitian. Pustaka Baru Press.

Zohar, D., \& Marshall, I. (2007). SQ: Kecerdasan Spiritual. PT Mizan Pustaka.

\begin{tabular}{|c|c|c|c|c|}
\hline Submit & Review & Revisi & Diterima & Publis \\
\hline 03-03-2021 & $\begin{array}{l}11-03-2021 \text { sd } 08-04- \\
2021\end{array}$ & $\begin{array}{l}\text { 31-03-2021 dan } \\
03-04-2021\end{array}$ & 06-04-2021 & $04-02-2022$ \\
\hline
\end{tabular}

Imam Syawali, Ahmad Suriadi, dan Shanty Komalasari

Program Studi Psikologi Islam

Fakultas Ushuluddin dan Humaniora

Universitas Islam Negeri Antasari Banjarmasin

E-mail: imamsyawali31@gmail.com 